\title{
Product Analysis of Caffeic Acid Oxidation by On-Line Electrochemistry/Electrospray Ionization Mass Spectrometry
}

\author{
Ryuichi Arakawa and Masashi Yamaguchi \\ Department of Applied Chemistry, Kansai University, Osaka, Japan
}

Hiroki Hotta and Toshiyuki Osakai

Department of Chemistry, Faculty of Science, Kobe University, Kobe, Japan

Takashi Kimoto

Research Institute of Oceano-Chemistry, Osaka, Japan

On-line electrochemistry/electrospray ionization mass spectrometry (EC/ESI-MS) was developed using a microflow electrolytic cell. This technique was applied to electrochemical oxidation of caffeic acid (CAF) which is known to be a highly antioxidative agent. Effects of electrolytic potentials on ion intensities of product ions and on electrolytic currents were examined at different $\mathrm{pHs}$. Dimer products were detected at electrolytic potentials of $\mathrm{E}=0.7$ $\mathrm{V}$ (vs. $\mathrm{Ag} / \mathrm{AgCl}$ ) and trimer products at $1.0 \mathrm{~V}$ at $\mathrm{pH}$ 9. Dimer products were distinguished from hydrogen-bonded complexes by MS/MS experiments. Hydrogen/deuterium exchange experiments determined the number of hydroxyl and carboxyl groups in the Dimers formed by electrolysis. The mechanism of oxidative polymerization of CAF is discussed with speculation as to the structure of the dimer product. (J Am Soc Mass Spectrom 2004, 15, 1228-1236) (C) 2004 American Society for Mass Spectrometry

$\mathrm{P}$ olyphenols (e.g., catechols, flavonoids, tannins), widely distributed in plants, are known to exhibit relatively high antioxidative activities [1]. The antioxidative reactions of polyphenols have been studied by means of absorption spectroscopy [2], pulse radiolysis [3-5], EPR [5], NMR [6, 7], HPLC [8-10], and also electrochemical methods including cyclic voltammetry [11-16] and flow coulometry [13-15]. In previous electrochemical studies [14-16], it was claimed that the higher radical scavenging activities of polyphenols can be ascribed to oxidative dimerization (or even higher degrees of polymerization) through which oxidizable $-\mathrm{OH}$ moieties are reproduced in the "oxidation" products. One of the possible mechanisms of oxidative dimerization for caffeic acid [14] (CAF) is shown in Figure 1. This mechanism is assumed to involve Dimer 1 being formed by a coupling reaction of the semiquinone radical as an intermediate of one-electron oxidation. Through the coupling reaction, two $-\mathrm{OH}$ moieties are regenerated, so that Dimer 1 possesses four $-\mathrm{OH}$ moieties. If Dimer $\mathbf{1}$ is further oxidized to Compound 2, four electrons will be involved in the oxidation of one

Published online July 9, 2004

Address reprint requests to Dr. R. Arakawa, Department of Applied Chemistry, Kansai University, Suita, Osaka 564-8680, Japan. E-mail: arak@ipcku.kansai-u.ac.jp molecule of Dimer 1. In this way, Compound 2 is obtained by oxidizing two molecules of CAF with six electrons. Although Compound 2 may undergo further polymerization and oxidation, three electrons have been involved, at this stage, in oxidizing the CAF monomer. This is in line with a previous observation that the number of electrons $(n)$ required for flowelectrolytic oxidation of CAF (as well as other polyphenols) was larger than that expected based on the number of $-\mathrm{OH}$ moieties in the molecules, i.e., $n>2[14,15]$. Although Dimer 1 and various other dimers of CAF are reportedly formed by chemical autooxidations [8, 9], the electrochemical oxidation products could not be isolated despite considerable effort [14, 15], because the dimer(s) was susceptible to further polymerization.

In this study, we employed an on-line electrochemistry/mass spectrometry (EC/MS) technique with a view to identifying unstable oxidation products of CAF. The idea of coupling an electrochemical flow cell to MS for the identification of non-volatile products was first realized by Hambitzer and Heitbaum, who connected a three-electrode flow cell to a thermospray mass spectrometer [17]. This approach was then extended to other ionization techniques, e.g., fast-atom bombardment [18], particlebeam [19] and electrospray [20-29] (see also a review [30] on EC/MS). Among the above ionization techniques, electrospray ionization (ESI), a soft ionization technique, is 


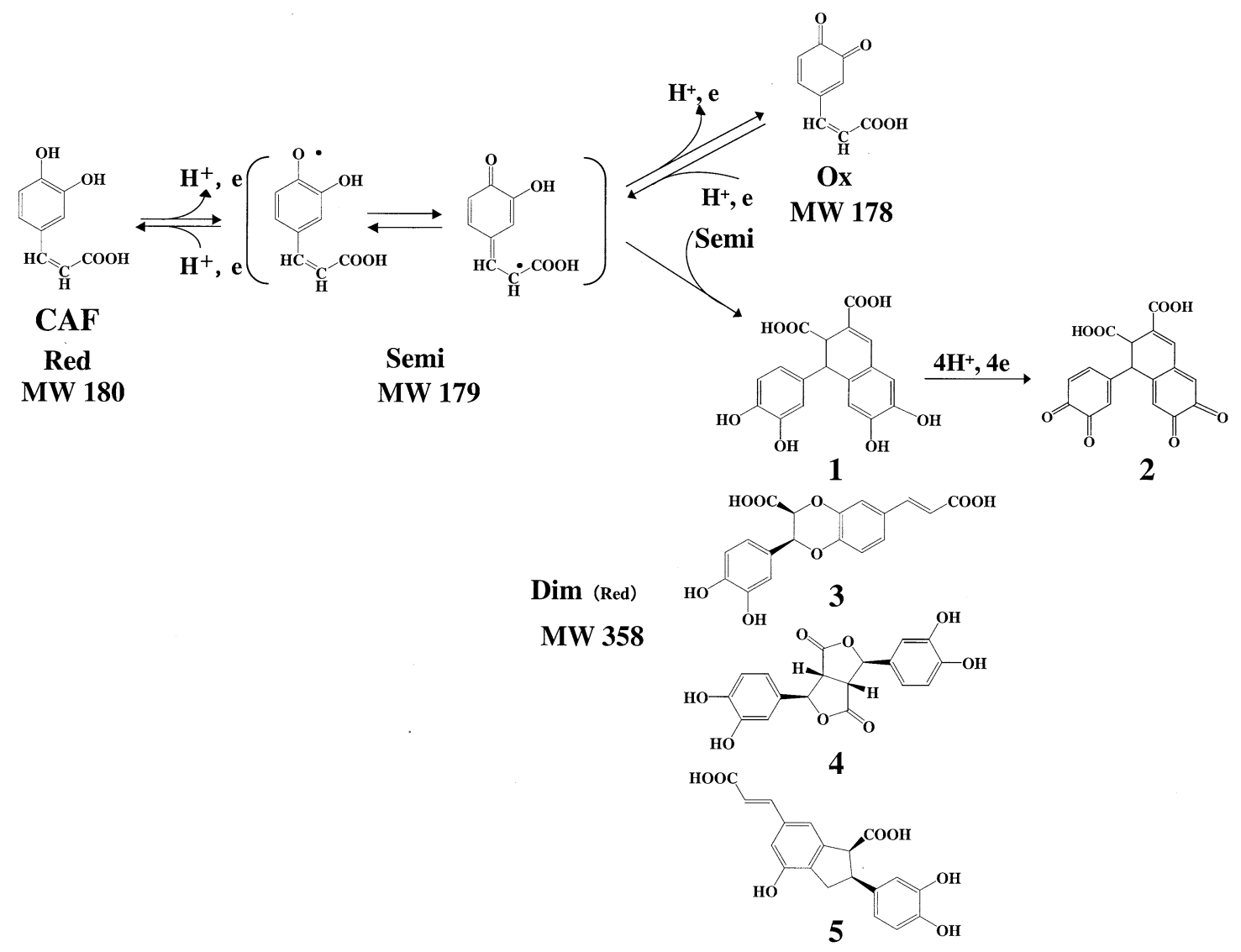

Figure 1. A possible mechanism of the oxidative dimerization of caffeic acid (CAF).

the most promising for application to thermally unstable compounds such as biomolecules. However, there have been only a few EC/ESI-MS studies on biologically relevant redox reactions. Deng and Van Berkel used a thinlayer electrochemical flow cell coupled on-line with ESI-MS to study the redox reaction of dopamine [27]. The two major oxidation products in aqueous methanol at $\mathrm{pH}$ 4 were identified as 5,6-dihydroxyindoline and 5,6-hydroxyindole. The Bruins group examined the possible use of EC/ESI-MS as a convenient means of mimicking phase I oxidative reactions in drug metabolism [28]. It should also be noted that EC/ESI-MS has been successfully employed by Van Berkel's group to study electrochemical polymerizations of aniline [25] and methylene blue [26].

We designed a microflow electrolytic cell which has a narrow flow channel $(0.5 \mathrm{~mm} \times 1.0 \mathrm{~mm} \times 14 \mathrm{~mm})$ tightly packed with carbon fiber as a working electrode. This microflow cell has allowed for $100 \%$ electrolysis at flow rates below $0.05 \mathrm{~mL} \mathrm{~min}^{-1}$. We then combined the microflow cell with ESI-MS for product analysis of the electrochemical oxidation of CAF.

\section{Experimental}

\section{Materials}

The special grade CAF was purchased from Nacalai Tesque Co. Ltd., Osaka, Japan and used without further purification. Ammonium acetate, acetic acid, sodium hydroxide, methanol, $\mathrm{d}_{2}$-water $(99.8 \%)$, and $\mathrm{d}_{4}$-methanol $(99.8 \%)$ were all obtained from Wako Pure Chemical Industries Ltd., Osaka, Japan.

\section{Sample Solutions}

The carrier solution was prepared by dissolving ammonium acetate $(1 \mathrm{mM})$ in water/methanol (20/80, vol/ vol), in which CAF was dissolved to make a $100 \mu \mathrm{M}$ solution. The $\mathrm{pH}$ of the sample solution was adjusted to 5,7 , or 9 with acetic acid or sodium hydroxide. For determination of the number of hydroxyl groups in the reaction products, the sample solution was prepared as described above except that $d_{2}$-water $/ d_{4}$-methanol was used instead of the undeuterated solvent mixture; the $\mathrm{pH}$ of the sample solution was adjusted to 9 with undeuterated sodium hydroxide.

\section{Microflow Cell}

Figure 2 shows the microflow cell (MFC). We assembled the three-electrode MFC (now available from Kimoto Electric Co.; model UE-491002; Osaka, Japan) as follows: A narrow channel was formed on a glassy carbon (GC) disk electrode embedded in a PVC pedestal using a PTFE gasket. The channel was tightly packed 


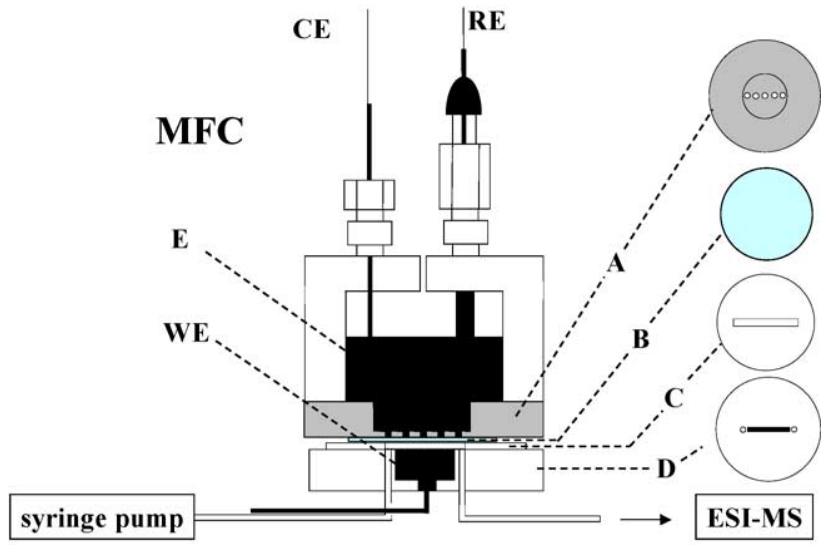

Figure 2. Schematic of a microflow cell (MFC) for EC/ESI-MS system: (A) Titanium, (B) dialysis membrane, (C) PTFE, (D) PVC, (E) $1 \mathrm{mM} \mathrm{CH}_{3} \mathrm{COONH}_{4}\left(\mathrm{H}_{2} \mathrm{O}: \mathrm{MeOH} 20 / 80\right.$ (vol/vol), (RE) Ag/ $\mathrm{AgCl}$ reference electrode, (CE) Pt counter electrode, (WE) glassy carbon working electrode.

with carbon fiber (supplied by Toray Industries Inc., Tokyo, Japan) and then covered with a dialysis membrane (Viskase Sales Corp., Willowbrook, IL; UC36-32100). The laminated structure was supported by downward pressure applied with a titanium disk with small holes for electric conduction, a cylindrical PVC lid with a platinum counter electrode, and six screws (not shown in the figure). Then, an electrolytic solution of the same composition as the carrier solution was poured into the MFC from the upper hole for insertion of a reference electrode. Finally, a $\mathrm{Ag} / \mathrm{AgCl}$ (sat. $\mathrm{KCl}$ ) reference electrode was furnished. The electrolytic potential was regulated by a potentiostat (Fuso Electrochemical System Co., Kawasaki, Japan; 1100L). The MFC was connected on-line with the ESI-MS system in the decoupled mode [20], as shown in Figure 2. The connecting tube was a $0.2 \mathrm{~mm}$ i.d. Teflon tube $(30 \mathrm{~cm}$ long). The electrolytic efficiency of the MFC was determined coulometrically for the oxidation of $\mathrm{Fe}(\mathrm{CN})_{6}^{4-}$ at various flow rates, as shown in Figure 3. A $20 \mu \mathrm{L}$ solution of $0.1 \mathrm{mM} \mathrm{K}_{4} \mathrm{Fe}(\mathrm{CN})_{6}$ containing $0.1 \mathrm{M} \mathrm{KCl}$ as a supporting electrolyte was injected and electrolyzed

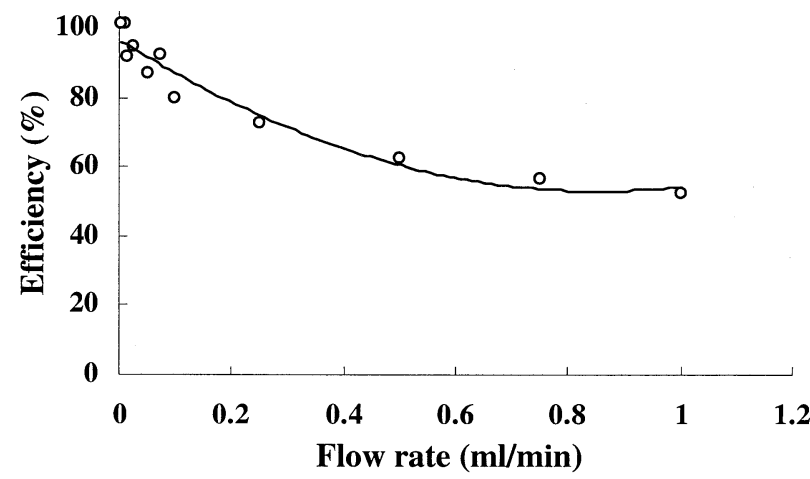

Figure 3. The flow-rate dependence of the electrolytic efficiency for MFC. A $20 \mu \mathrm{L}$ solution of $0.1 \mathrm{mM} \mathrm{K}_{4} \mathrm{Fe}(\mathrm{CN})_{6}$ containing $0.1 \mathrm{M}$ $\mathrm{KCl}$ was injected and electrolyzed at $\mathrm{E}=0.7 \mathrm{~V}$ vs. $\mathrm{Ag} / \mathrm{AgCl}$. at $\mathrm{E}=0.7 \mathrm{~V}$ vs. $\mathrm{Ag} / \mathrm{AgCl}$. Almost $100 \%$ electrolytic efficiency was attained at flow rates below $0.05 \mathrm{~mL}$ $\min ^{-1}$. This was the case even when the $0.1 \mathrm{M} \mathrm{KCl}$ was changed to a $1 \mathrm{mM}$ ammonium-acetate water/methanol solution (i.e., the carrier solution for the MS experiments).

\section{MS Measurements}

The mass spectra were obtained with a triple stage quardrupole mass spectrometer TSQ 700 (Finnigan MAT, San-Jose, CA). Analyses were consistently carried out in negative ion mode. The electrolyses of sample solutions were performed at a sufficiently low flow rate $\left(5 \mu \mathrm{L} \mathrm{min}{ }^{-1}\right)$ and the solutions were electrosprayed directly for the mass spectrometric analysis. The electrospray potential was $-4.5 \mathrm{kV}$ and the heated capillary temperature used was $200{ }^{\circ} \mathrm{C}$.

\section{Results and Discussion}

\section{Monomeric Products}

First, we investigated changes in the electrolytic products of CAF at different pHs. In Figure 4, the mass spectra obtained at $\mathrm{pH} 9$ with electrolytic potentials $\mathrm{E}=$ (Figrue $4 \mathrm{a}$ ) $0 \mathrm{~V}$ and (Figure $4 \mathrm{~b}) 1.0 \mathrm{~V}$ (vs. $\mathrm{Ag} / \mathrm{AgCl}$ ) are shown. The peaks of monomeric electrolysis products are shown, with magnification, in Figure 4. As shown by a cyclic voltammetric study [16], the reduced form of CAF (Red) undergoes reversible two-electron oxidation. Under the $\mathrm{pH}$ conditions used in this study ( $\mathrm{pH}$ 5-9), CAF is not oxidized at $\mathrm{E}=0 \mathrm{~V}$, but is completely oxidized at $\mathrm{E}=1.0 \mathrm{~V}$. Accordingly, the initial product at $\mathrm{E}=1.0 \mathrm{~V}$ should be the two-electron oxidized form of CAF (Ox), though this oxidation may be followed by dimerization or even higher degrees of polymerization of products in the higher $\mathrm{pH}$ range ( $>9$ ). Thus, the $\mathrm{m} / \mathrm{z}$ 179 ion formed at $\mathrm{E}=0$ is a deprotonated ion of the reduced form of CAF [Red $-\mathrm{H}]^{-}$, and the $\mathrm{m} / \mathrm{z} 177$ ion formed at $\mathrm{E}=1.0$ is a deprotonated ion of the twoelectron oxidized form of CAF $[\mathrm{Ox}-\mathrm{H}]^{-}$. This twoelectron oxidized form was observed at all $\mathrm{pHs}(5,7$ and 9) examined. The electrolytic mass spectra obtained with pH 5 and 7 solutions were almost the same, but were different from the spectrum with $\mathrm{pH} 9$; the ion intensities of electrolytic products (i.e., $m / z 357$ and 535 ions) were greater with $\mathrm{pH} 9$ than with $\mathrm{pH} 5$ or 7 .

Changes in ion intensities and electrolytic currents with different electrolytic potentials were then examined (Figure 5). As the ion intensity of the reduced form $[\text { Red }-\mathrm{H}]^{-}(\mathrm{m} / \mathrm{z}$ 179) decreased, an increase in the two-electron oxidized form [Ox $-\mathrm{H}]^{-}(\mathrm{m} / \mathrm{z} 177)$ was observed, while the intensity of the semiquinone [Semi $-\mathrm{H}^{-}(\mathrm{m} / \mathrm{z} 178)$ remained essentially unchanged. The one electron oxidation product of the semiquinone radical was not detected at $\mathrm{m} / \mathrm{z} 178$ (no correction of ${ }^{13} \mathrm{C}$ isotope from $\mathrm{m} / \mathrm{z}$ 177). At the same time, it is important to note that when the $\mathrm{pH}$ of the solution was increased, 

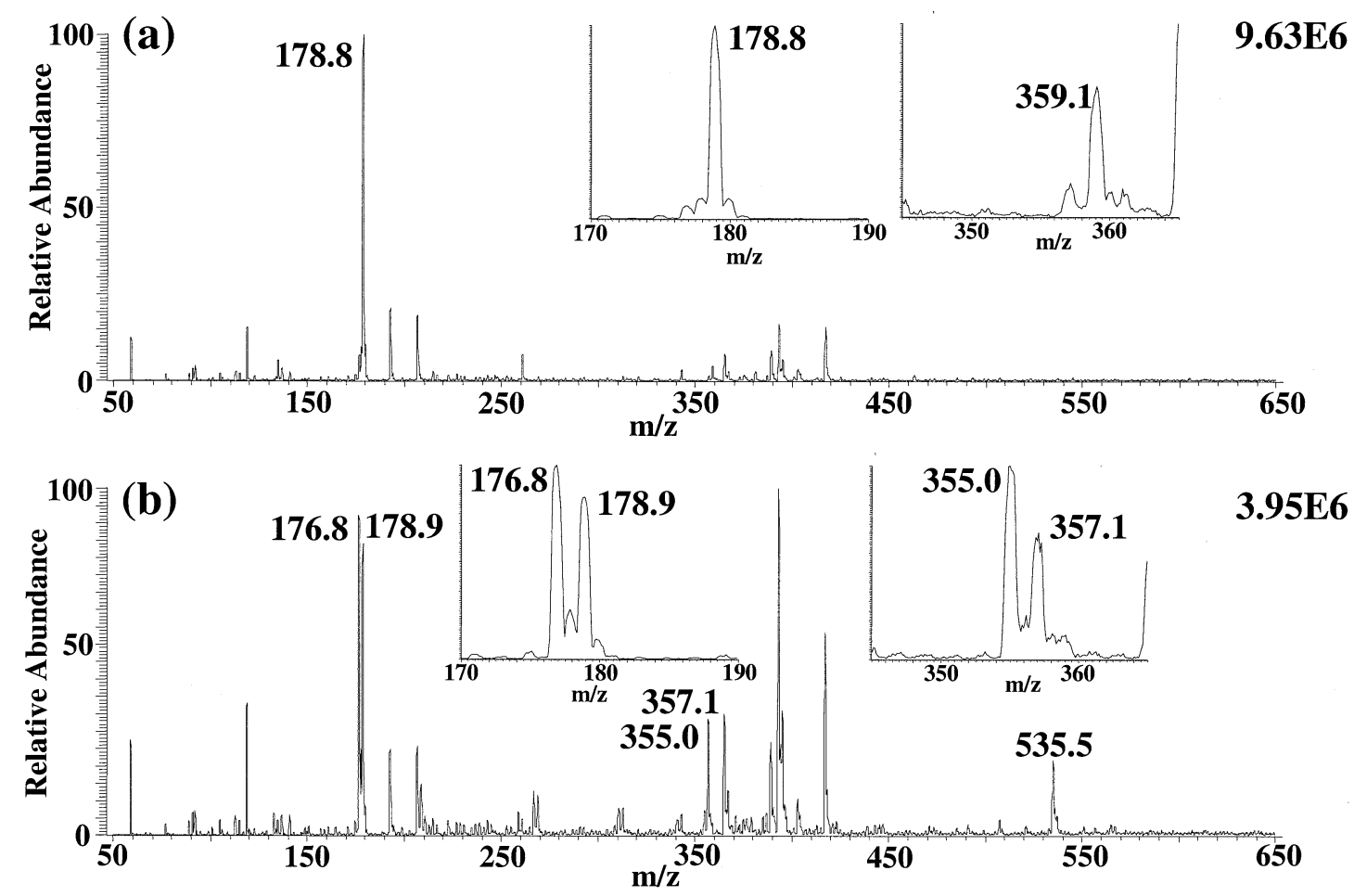

Figure 4. The negative ion ESI mass spectra obtained at $\mathrm{pH} 9$ with electrolytic potentials of $\mathrm{E}=(\mathrm{a})$ $0 \mathrm{~V}$ and $(\mathrm{b}) 1.0 \mathrm{~V}$ (vs. $\mathrm{Ag} / \mathrm{AgCl}$ ). The figures on the right represent the signal intensity of a base peak indicated by TSQ 700 .
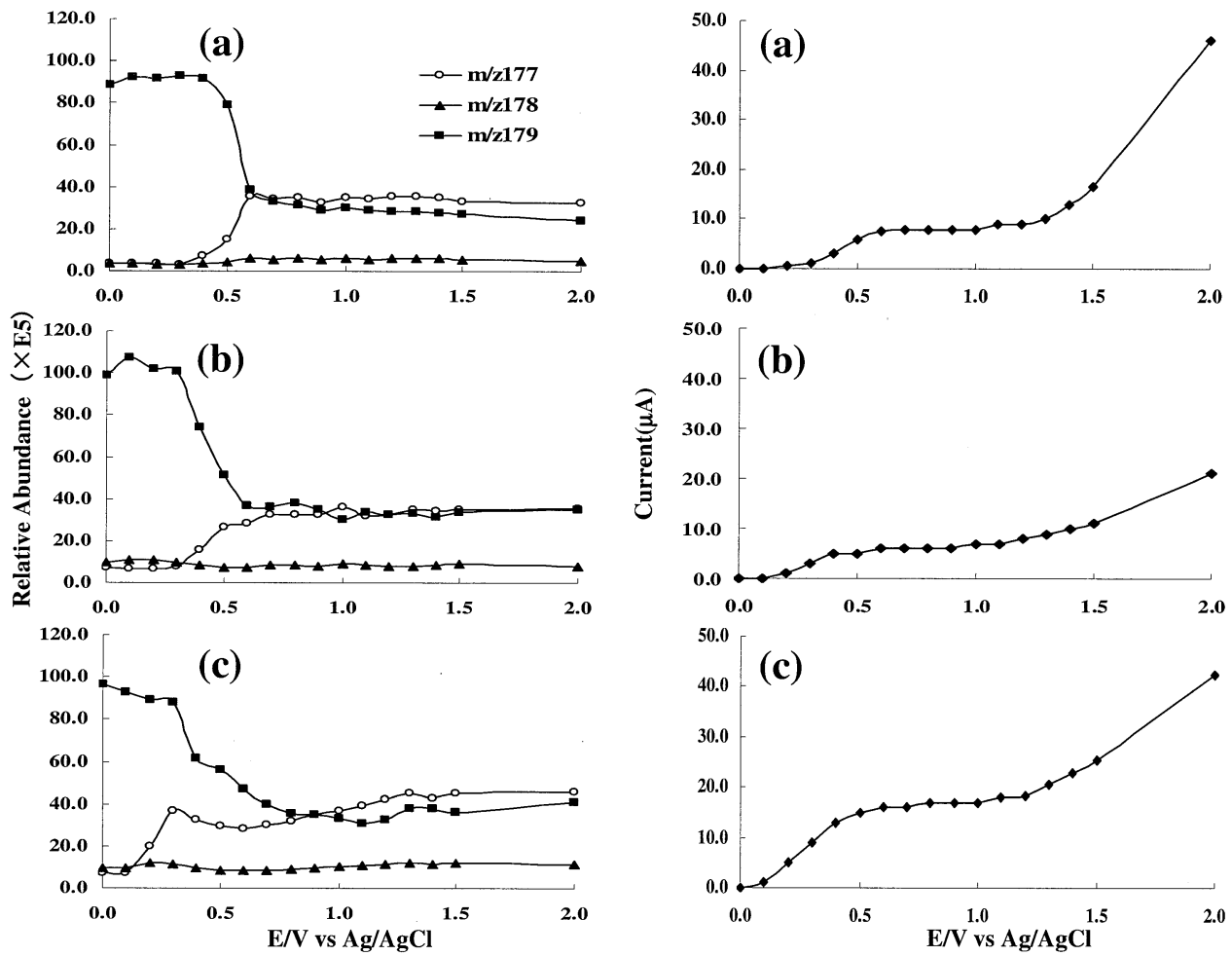

Figure 5. The potential dependences of the $m / z 177,178$, and 179 ion intensities and of the electrolytic currents; (a) $\mathrm{pH}$ 5, (b) $\mathrm{pH} 7$, and (c) $\mathrm{pH} 9$. 
the oxidation potential, i.e., the potential at which the ion intensity of the major oxidation product $(\mathrm{m} / \mathrm{z} 177)$ and the electrolytic current increased significantly, shifted to lower values showing that CAF is more easily oxidized at a higher $\mathrm{pH}$. This is because two protons are released for the two-electron oxidation of CAF via the semiquinone, as previously described by Hotta et al. [16].

\section{Dimeric Products}

The ions observed in the $m / z$ range of 355-360 were then examined (Figure 4). The $\mathrm{m} / \mathrm{z} 359$ ion observed at $\mathrm{E}=0$ $\mathrm{V}$ was considered to be a deprotonated ion of a dimeric complex formed by hydrogen bonding of two reduced forms of $\mathrm{CAF}$, namely $[2 \mathrm{Red}-\mathrm{H}]^{-}$. The intensity of the $\mathrm{m} / \mathrm{z} 359$ ion decreased when the electrolytic potential was increased to $\mathrm{E}=1.0 \mathrm{~V}$, and simultaneously, two new peaks appeared at $m / z 355$ and 357. Similar changes in the mass spectra were observed when the electrolyses were carried out at different $\mathrm{pHs}$. Accordingly, the $\mathrm{m} / \mathrm{z} 357$ ion could be assigned to a deprotonated dimer formed during electrolytic oxidation, $\left[\operatorname{Dim}_{(\mathrm{Red})}-\mathrm{H}\right]^{-}$ (Figure 1), or to a deprotonated, hydrogen-bonded complex formed between the oxidized and reduced forms of CAF, [Red $+\mathrm{Ox}-\mathrm{H}]^{-}$. The $m / z 355$ ion also has two possible sources; one is a deprotonated dimer formed by two-electron oxidation $\left[\operatorname{Dim}_{(\mathrm{Ox})}-\mathrm{H}\right]^{-}$, and the other is a deprotonated complex formed by hydrogen bonding between two molecules of oxidized CAF, $[2 \mathrm{Ox}-\mathrm{H}]^{-}$. This raises the question of why the dimer of the reduced form, $\operatorname{Dim}_{(\mathrm{Red})}$, is detected at the higher electrolytic potential despite complete oxidation being expected in the cell. Two explanations can be outlined at the present time; one involves the semiquinone formed by oxidation being polymerized outside of the cell, though a portion of the semiquinone would presumably be polymerized within the cell, and the other is that the oxidized dimer $\operatorname{Dim}_{(\mathrm{Ox})}$ is reduced at the ESI needle.

In order to confirm the above assignments and determine whether the uncertain product ions are dimeric or hydrogen-bonded, we examined the effects of electrolytic potential on the ion intensities of the uncertain product ions (Figure 6). At all $\mathrm{pHs}$ tested (5, 7, and 9), the intensity of the $\mathrm{m} / \mathrm{z} 359$ ion decreased with increasing electrolytic potential, suggesting that the complex, [2Red $-\mathrm{H}]^{-}$, formed by hydrogen bonding of two reduced forms of CAF was decreased by electrolysis. However, the $m / z 355$ and 357 ions showed different potential dependences of their intensities at the higher $\mathrm{pH}$ of 9. At lower $\mathrm{pHs}$ ( 5 and 7 ), the intensities of both $\mathrm{m} / \mathrm{z} 355$ and the 357 ions were increased at approximately $0.5 \mathrm{~V}$ and leveled off at higher potentials (Figure 6a and b). The results allow us to conclude simply that the $\mathrm{m} / \mathrm{z} 355$ and 357 ions constitute a complex formed between two oxidized forms, [2Ox $\mathrm{H}]$, and one involving an oxidized form and a reduced form, $[\mathrm{Red}+\mathrm{Ox}-\mathrm{H}]^{-}$, respectively. The formation of
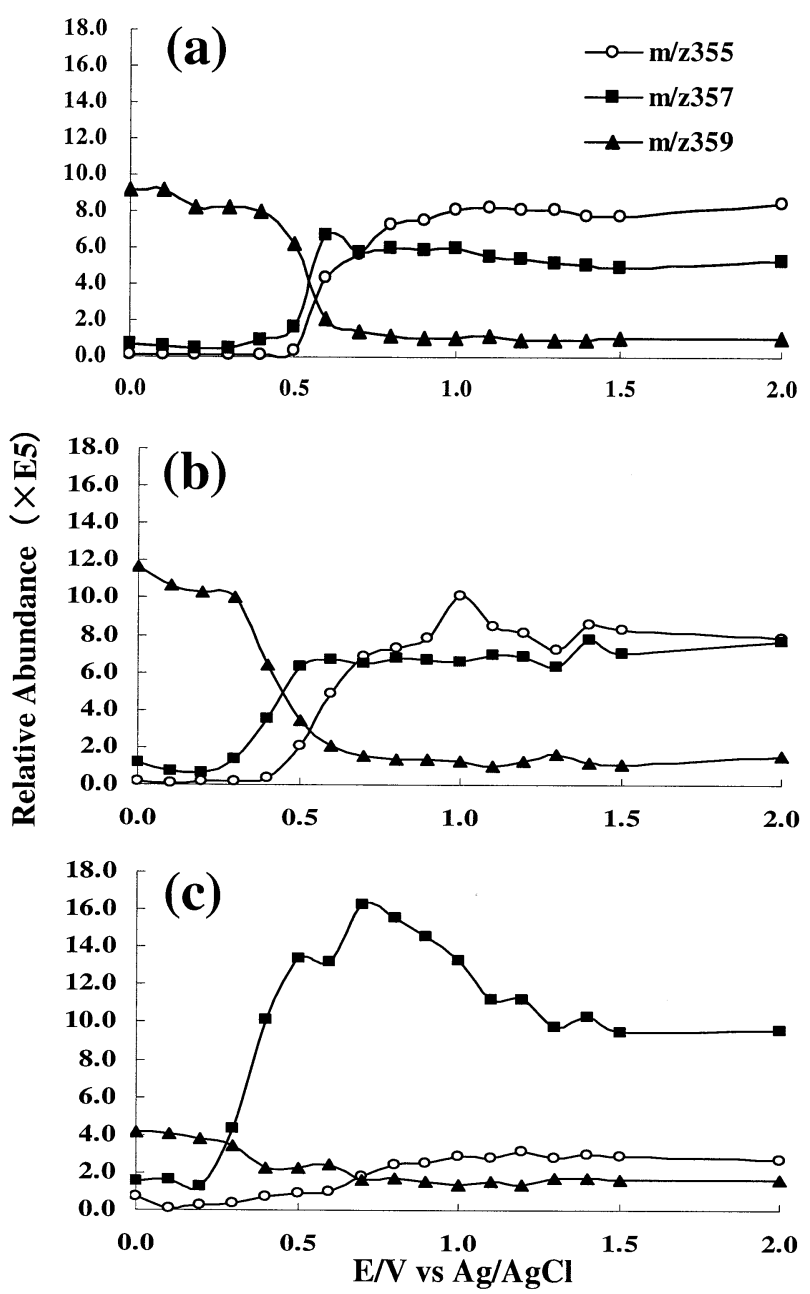

Figure 6. The potential dependences of the $m / z$ 355, 357, and 359 ion intensities; (a) $\mathrm{pH}$ 5, (b) $\mathrm{pH} 7$, and (c) $\mathrm{pH} 9$.

the latter complex including a reduced form at higher potentials would be accounted for by unfavorable reduction of the oxidized CAF at the ESI needle. At $\mathrm{pH} 9$, however, the intensity of the $\mathrm{m} / \mathrm{z} 357$ ion showed a prominent peak at approximately $0.7 \mathrm{~V}$, while the intensity of the $\mathrm{m} / \mathrm{z} 355$ ion started to increase at $0.7 \mathrm{~V}$, i.e., the voltage at which the intensity of the $\mathrm{m} / \mathrm{z} 357$ ion began to fall (Figure 6c). This would suggest that at $\mathrm{pH}$ 9, the two ions, $m / z 355$ and 357 , are in the relation of oxidized and reduced forms. We then assigned the respective ions to $\left[\operatorname{Dim}_{(\mathrm{Red})}-\mathrm{H}\right]^{-}$and its two-electron oxidized form, $\left[\operatorname{Dim}_{(\mathrm{Ox})}-\mathrm{H}\right]^{-}$. These assignments to the dimeric complexes at $\mathrm{pH} 9$ are supported by previous electrochemical studies [14-16].

The electrolytic current at a sufficiently positive potential $(1.0 \mathrm{~V})$, being measured simultaneously with the mass spectra shown in Figure 5, was about $10 \mu \mathrm{A}$ at $\mathrm{pH} 5$ and 7 , but 1.5 times higher at $\mathrm{pH} 9$. The electrolytic current measured at a constant flow rate should be proportional to the number of electrons $(n)$, therefore $n$ can be estimated to be about 3 for $\mathrm{pH} 9$ (note that CAF is oxidized by 2 electrons at lower $\mathrm{pHs}$ ). This is consis- 


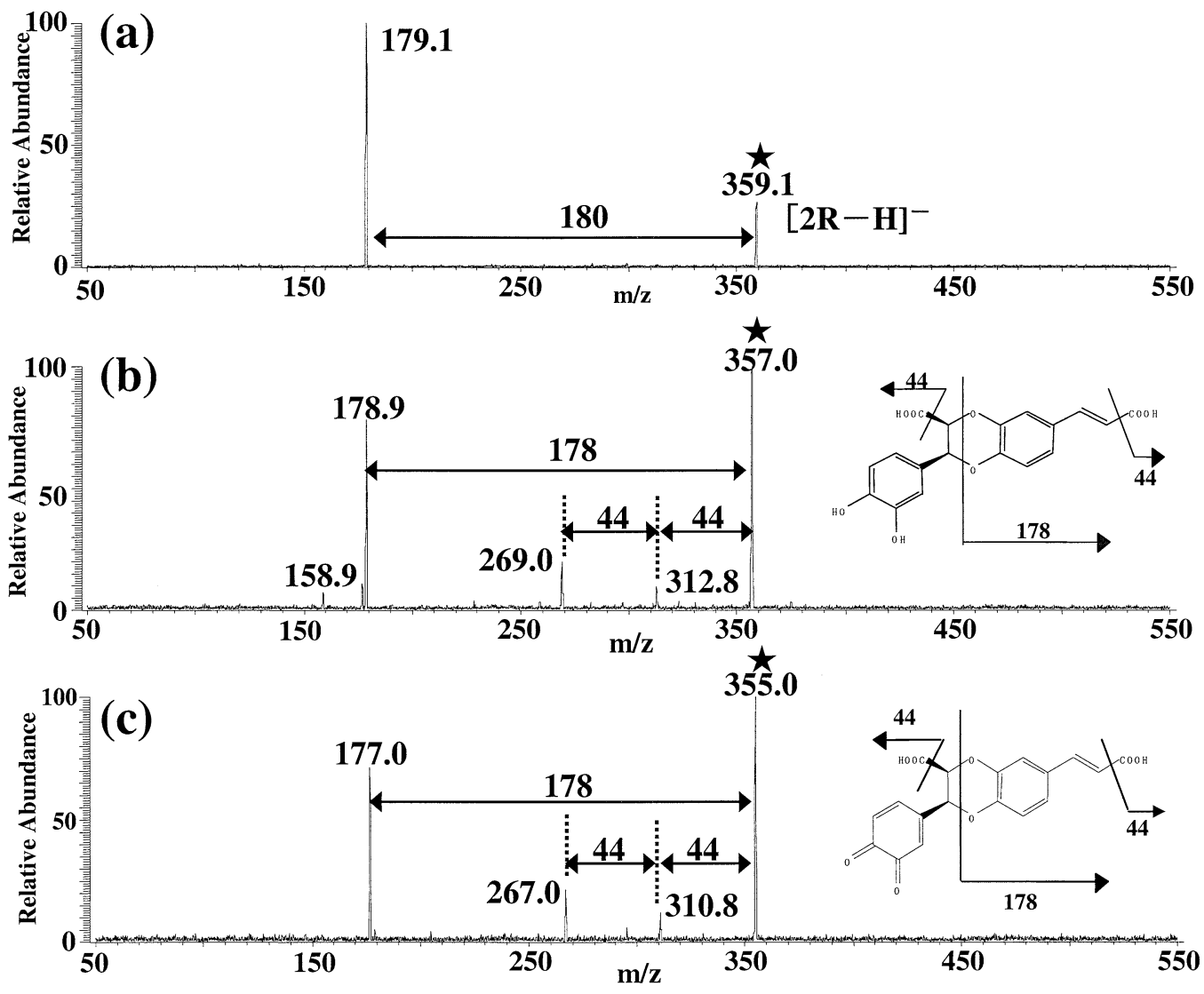

Figure 7. The MS/MS spectra of (a) $m / z 359$ ion obtained at $\mathrm{E}=0$, (b) $m / z 357$, and (c) $m / z 355$ ions obtained at $\mathrm{E}=1.0 \mathrm{~V}$ (vs. $\mathrm{Ag} / \mathrm{AgCl}$ ).

tent with the previous result that $n$ increases with $\mathrm{pH}$ and exceeds 2 at $\mathrm{pH}>7$ [14]. The increase in $n$ with $\mathrm{pH}$ is due to the formation of CAF dimers and/or multimers.

The MS/MS experiments were carried out in order to confirm that the $\mathrm{m} / \mathrm{z} 355$ and 357 ions at $\mathrm{pH} 9$ are indeed dimeric products, not hydrogen-bonded complexes. The MS/MS spectrum of the complex ion $\mathrm{m} / \mathrm{z}$ 359, [2Red $-\mathrm{H}]^{-}$, obtained at $\mathrm{E}=0 \mathrm{~V}$, exhibited a simple spectrum with a single peak due to the elimination of one CAF molecule from the parent ion (Figure 7a). On the other hand, the MS/MS spectra of ions $\mathrm{m} / \mathrm{z}$ 355 and 357 obtained at $\mathrm{E}=1.0 \mathrm{~V}$ (Figure $7 \mathrm{~b}$ and c) both showed two ions produced by the elimination of 44 and $88 \mathrm{Da}$ from the parent ions. The production of these two ions must be attributable to the elimination of $\mathrm{CO}_{2}$ from the carboxyl groups in the parent dimer ions. If the $\mathrm{m} / \mathrm{z}$ 355 and 357 ions were hydrogen-bonded complexes, the dissociation of complex ions should occur preferentially to yield only the $\mathrm{m} / \mathrm{z} 179$ or the 177 ion, not generating a $\mathrm{CO}_{2}$ elimination ion as in the spectrum shown in Figure 7a. In addition, the MS/MS spectrum of $\mathrm{m} / \mathrm{z} 357$ generated a fragment ion of $m / z 159$. This fragment was not detected in the MS/MS spectra of $\mathrm{m} / \mathrm{z} 179$ [Red $\mathrm{H}]^{-}$and $177[\mathrm{Ox}-\mathrm{H}]^{-}$ions. This also suggests that the $\mathrm{m} / \mathrm{z} 357$ ion is a dimer product. However, the $\mathrm{m} / \mathrm{z} 159$ fragment was not observed for the $m / z 355$ ion. Finally, the $\mathrm{m} / \mathrm{z} 355$ and 357 ions formed by electrolysis at $\mathrm{pH} 9$ were confirmed to be the dimer ions $\left[\operatorname{Dim}_{(\mathrm{Ox})}-\mathrm{H}\right]^{-}$ and $\left[\mathrm{Dim}_{(\mathrm{Red})}-\mathrm{H}\right]^{-}$, respectively.

\section{Trimer Products}

As seen in Figure 4, there were no peaks in the area of the $m / z 535$ ion when the spectrum was obtained at an electrolytic potential of $\mathrm{E}=0 \mathrm{~V}$ but the spectrum obtained at $\mathrm{E}=1.0 \mathrm{~V}$ exhibited two ions of $\mathrm{m} / \mathrm{z} 535$ and 507. These high mass ions as electrolysis products were observed at $\mathrm{pH} 7$ and 9 , but not at $\mathrm{pH} 5$. The $\mathrm{m} / \mathrm{z} 535$ ion could be a trimer of CAF, [Tri $-\mathrm{H}]^{-}$(Tri: mw 536), or a complex formed between the two-electron oxidized form of a CAF dimer and a reduced CAF, $\left[\mathrm{Dim}_{(\mathrm{Ox})}+\right.$ Red $-\mathrm{H}]^{-}$. Next, the effects of electrolytic potential on the $m / z 507$ and $m / z 535$ ions were studied (Figure 8). At all pHs tested, the ion intensity of the $\mathrm{m} / \mathrm{z} 535$ ion was increased at approximately $0.6 \mathrm{~V}$ until it reached a peak, but the increase was remarkable at $\mathrm{pH} 9$. It should also be noted that the potential for the $\mathrm{m} / z 535$ ion at $\mathrm{pH} 9$ is 0.2-0.3 V higher than that for the $\mathrm{m} / \mathrm{z} 355$ ion, as shown in Figure 6c. These results raise the possibility that the $\mathrm{m} / \mathrm{z} 535$ ion is the trimer, $[\operatorname{Tri}-\mathrm{H}]^{-}$, generated via formation of the dimer and its subsequent oxidation. 


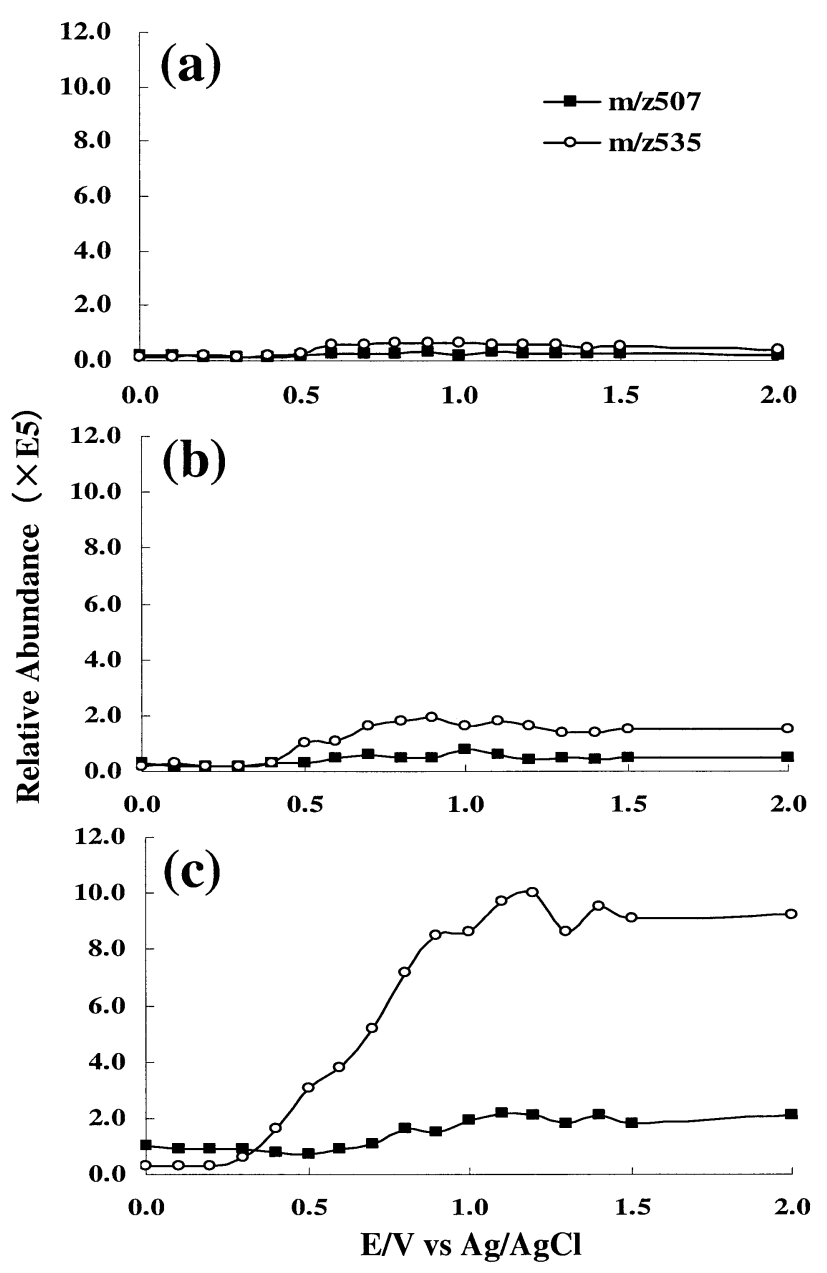

Figure 8. The potential dependences of the $m / z 507$ and 535 ion intensities; (a) $\mathrm{pH} 5,(\mathbf{b}) \mathrm{pH} 7$, and (c) $\mathrm{pH} 9$.

\section{H/D Exchange Experiments}

In order to determine the number of hydroxyl groups in the dimers formed by electrolysis, electrolysis was carried out in a deuterated solvent at $\mathrm{pH} 9$. At $\mathrm{E}=0 \mathrm{~V}$, the spectrum exhibited three ions at $m / z 179,180$ and 181 (Figure 9a). The appearance of three peaks near $\mathrm{m} / \mathrm{z}$ 180 is due to the partial deuterium exchange of the hydroxyl groups in CAF. The spectrum obtained at $\mathrm{E}=$ $1.0 \mathrm{~V}$ showed a cluster of multiple ions at the mass range of dimers. The effects of electrolytic potential on these dimeric ions were further examined (Figure 10). The $m / z 357 \sim 360$ ion intensities started to increase at around $0.3 \mathrm{~V}$, then fell to a constant level (Figure 10a). In contrast, the potential dependence of the intensities of the $m / z 355$ and 356 ions did not show a peak but rather an S-shaped curve (Figure 10b). The oxidation potential of the $\mathrm{m} / \mathrm{z} 355$ and 356 ions, i.e., $0.5 \mathrm{~V}$, coincided with the potential at which the intensities of the $m / z 357 \sim 360$ ions started to decrease. This relation is identical to that observed above for $\left[\operatorname{Dim}_{(\mathrm{Ox})}-\mathrm{H}\right]^{-}$ $(m / z 355)$ and $\left[\operatorname{Dim}_{(\mathrm{Red})}-\mathrm{H}\right]^{-}(\mathrm{m} / \mathrm{z} 357)$. Therefore, the multiple ions at $m / z 357 \sim 360$ are likely to be among the deuterium exchanged dimeric ions.

The hydrogen/deuterium (H/D) exchanges in CAF could occur in both the hydroxyl and carboxyl groups. Among possible isomeric structures of the reduced forms of dimers $\left(\operatorname{Dim}_{(\mathrm{Red})}\right)$ shown in Figure 1, Structure 1 should yield multiple ions at $\mathrm{m} / z 357 \sim 362$ in the H/D exchange spectrum, because it possesses five exchanged sites. Similarly, Structure 3 with three exchanged sites should yield multiple ions at $\mathrm{m} / \mathrm{z} 357 \sim$ 360, and Structures 5 and $\mathbf{6}$ with four sites those at $\mathrm{m} / \mathrm{z}$ $357 \sim 361$. In practice, the results of $H / D$ exchange

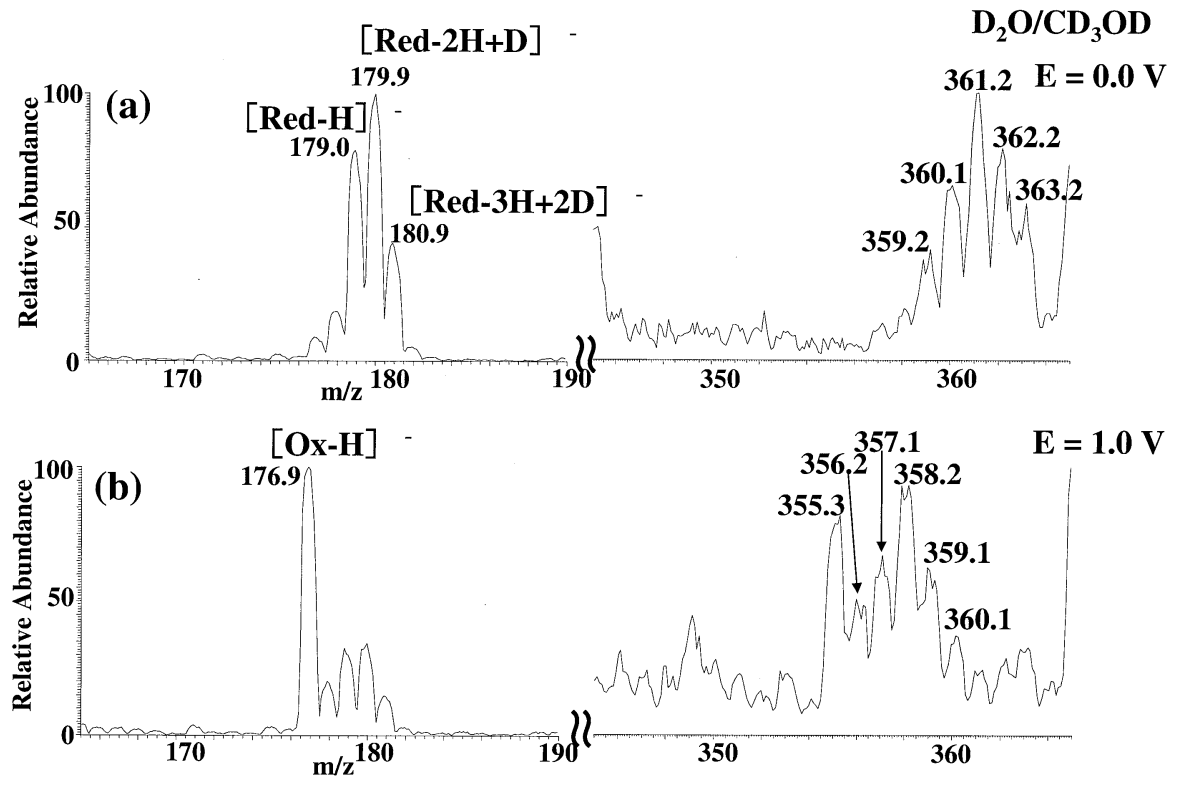

Figure 9. The negative ion ESI mass spectra with use of a deuterated solvent at $\mathrm{pH} 9 ; \mathrm{E}=(\mathbf{a}) 0 \mathrm{~V}$ and (b) $1.0 \mathrm{~V}$ (vs. Ag/AgCl). 


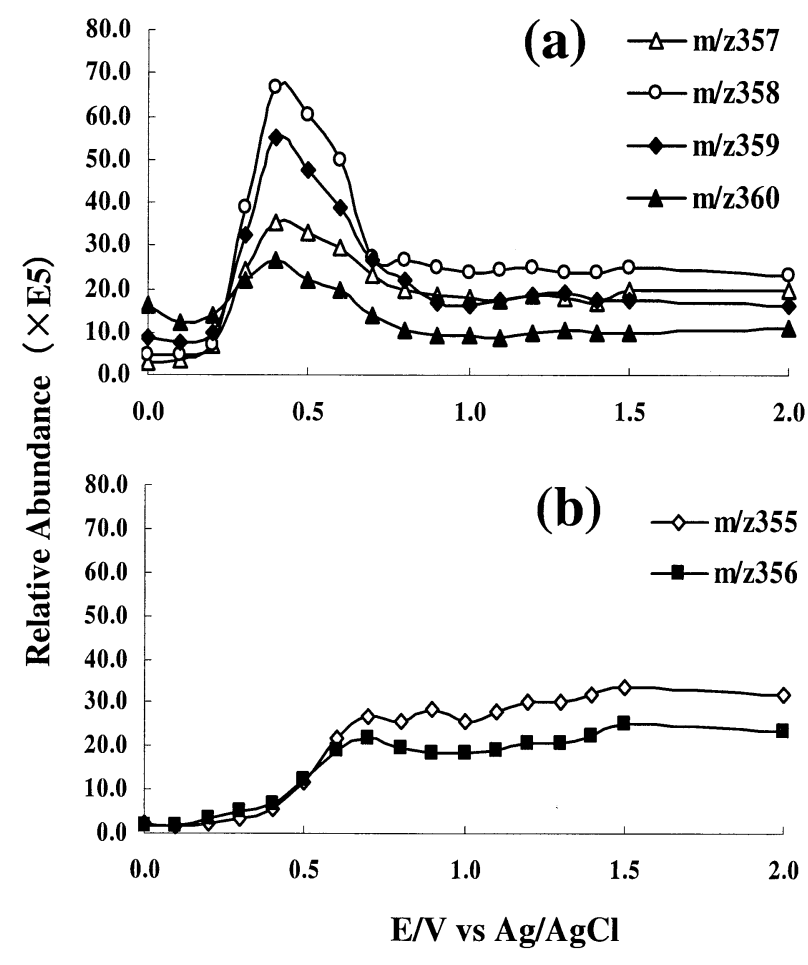

Figure 10. The potential dependences of the ion intensities of $\mathrm{m} / \mathrm{z}$ 355-360 ions obtained at $\mathrm{pH} 9$.

showed multiple ions of $m / z 357 \sim 360$, suggesting that the dimer has Structure 3 . The oxidized dimer ion $\left[\operatorname{Dim}_{(\mathrm{Ox})}-\mathrm{H}\right]^{-}$, which has no hydroxyl group as a H/D exchanged site, appeared at $\mathrm{m} / \mathrm{z} 355$ and 356. These results also support our view that the dimer ion is Structure 3.

Dimers containing several hydroxyl groups were not observed in the H/D exchange experiment. This may be due to rapid polymerization of such dimers to multimers.

\section{Acknowledgments}

This research was partly supported by a Grant-in-Aid for Scientific Research (C) from the Ministry of Education, Culture, Sports, Science and Technology and by Kansai University Research Grants (Joint Research, 2003).

\section{References}

1. (a) Rice-Evans, C. A.; Miller, N. J.; Paganga, G. Antioxidant Properties of Phenolic Compounds. Trends Plant Sci. 1997, 2, 152-159. (b) Larson, R. A. The Antioxidants of Higher-Plants. Phytochemistry 1988, 27, 969-978. (c) Harborne, J. B.; Williams, C. A. Advances in Flavonoid Research Since 1992. Phytochemistry 2000, 55, 481-504.

2. Blois, M. S. Antioxidant Determinations by the Use of a Stable Free Radical. Nature 1958, 181, 1199-1200.

3. Jovanovic, S. V.; Hara, Y.; Steenken, S.; Simic, M. G. Antioxidant Potential of Gallocatechins-a Pulse-Radiolysis and Laser Photolysis Study. J. Am. Chem. Soc. 1995, 117, 9881-9888.

4. Kono, Y.; Kobayashi, K.; Tagawa, S.; Adachi, K.; Ueda, A.; Sawa, Y.; Shibata, H. Antioxidant Activity of Polyphenolics in
Diets-Rate Constants of Reactions of Chlorogenic Acid and Caffeic Acid with Reactive Species of Oxygen and Nitrogen. Biochim. Biophys. Acta 1997, 1335, 335-342.

5. Bors, W.; Michel, C.; Stettmaier, K.; Lu, Y. R.; Foo, L. Y. Pulse Radiolysis, Electron Paramagnetic Resonance Spectroscopy, and Theoretical Calculations of Caffeic Acid Oligomer Radicals. Biochim. Biophys. Acta 2003, 1620, 97-107.

6. Tazaki, H.; Taguchi, D.; Hayashida, T.; Nabeta, K. Stable Isotope-Labeling Studies on the Oxidative Coupling of Caffeic Acid via o-Quinone. Biosci. Biotech. Biochem. 2001, 65, 26132621.

7. Tazaki, H.; Ito, M.; Miyoshi, M.; Kawabata, J.; Fukushi, E.; Fujita, T.; Motouri, M.; Furuki, T.; Nabeta, K. Subulatin, an Antioxidic Caffeic Acid Derivative Isolated from the in Vitro Cultured Liverworts Jungermannia subulata, Lophocolea heterophylla, and Scapania parvitexta. Biosci. Biotech. Biochem. 2002, 66, 255-261.

8. Cilliers, J. J. L.; Singleton, V. L. Characterization of the Products of Nonenzymic Autoxidative Phenolic Reactions in a Caffeic Acid Model System. J. Agric. Food Chem. 1991, 39, 1298-1303.

9. Fulcrand, H.; Cheminat, A.; Brouillard, R.; Cheynier, V. Characterization of Compounds Obtained by Chemical Oxidation of Caffeic Acid in Acidic Conditions. Phytochemistry 1994, 35, 499-505.

10. Koleva, I. I.; Niederländer, H. A. G.; Van Beek, T. A. An On-line HPLC Method for Detection of Radical Scavenging Compounds in Complex Mixtures. Anal. Chem. 2000, 72, 2323-2328.

11. Born, M.; Carrupt, P.-A.; Zini, R.; Brée, F.; Tillement, J.-P.; Hostettmann, K.; Testa, B. Electrochemical Behavior and Antioxidant Activity of Some Natural Polyphenols. Helv. Chim. Acta 1996, 79, 1147-1158.

12. Hapiot, P.; Neudeck, A.; Pinson, J.; Fulcrand, H.; Neta, P.; Rolando, C. Oxidation of Caffeic Acid and Related Hydroxycinnamic Acids. J. Electroanal. Chem. 1996, 405, 169-176.

13. Hendrickson, H. P.; Sahafayen, M.; Bell, M. A.; Kaufman, A. D.; Hadwiger, M. E.; Lunte, C. E. Relationship of Flavonoid Oxidation Potential and Effect on Rat Hepatic-Microsomal Metabolism of Benzene and Phenol. J. Pharm. Biomed. Anal. 1994, 12, 335-341.

14. Hotta, H.; Sakamoto, H.; Nagano, S.; Osakai, T.; Tsujino, Y. Unusually Large Numbers of Electrons for the Oxidation of Polyphenolic Antioxidants. Biochim. Biophys. Acta 2001, 1526, 159-167.

15. Hotta, H.; Nagano, S.; Ueda, M.; Tsujino, Y.; Koyama, J.; Osakai, T. Higher Radical Scavenging Activities of Polyphenolic Antioxidants can be Ascribed to Chemical Reactions Following Their Oxidation. Biochim. Biophys. Acta 2002, 1572, 123-132.

16. Hotta, H.; Ueda, M.; Nagano, S.; Tsujino, Y.; Koyama, J.; Osakai, T. Mechanistic Study of the Oxidation of Caffeic Acid by Digital Simulation of Cyclic Voltammograms. Anal. Biochem. 2002, 303, 66-72.

17. Hambitzer, G.; Heitbaum, J. Electrochemical Thermospray Mass-Spectrometry. Anal. Chem. 1986, 58, 1067-1070.

18. Bartmess, J. E.; Phillips, L. R. Electrochemically Assisted Fast-Atom-Bombardment Mass-Spectrometry. Anal. Chem. 1987, 59, 2012-2014.

19. (a) Regino, M. C. S.; Brajter-Toth, A. An Electrochemical Cell for On-Line Electrochemistry Mass Spectrometry. Anal. Chem. 1997, 69, 5067-5072. (b) Regino, M. C. S.; Weston, C.; BrajterToth, A. Effect of Mobile Phase Composition on the Electrochemical Cell Conversion Efficiency in Electrochemistry/ Mass Spectrometry. Anal. Chim. Acta 1998, 369, 253-262. (c) Regino, M. C. S.; Brajter-Toth, A. Real Time Characterization of Catalysis by On-Line Electrochemistry Mass Spectrometry. 
Investigation of Quinone Electrocatalysis of Amine Oxidation. Electroanalysis 1999, 11, 374-379. (d) Zhang, T. Y.; Brajter-Toth, A. On-Line Investigation of the Generation of Nonaqueous Intermediate Radical Cations by Electrochemistry/Mass Spectrometry. Anal. Chem. 2000, 72, 2533-2540.

20. Zhou, F.; Van Berkel, G. J. Electrochemistry Combined OnLine with Electrospray Mass-Spectrometry. Anal. Chem. 1995, 67, 3643-3649.

21. Bond, A. M.; Colton, R.; D'Agostino, A.; Downard, A. J.; Traeger, J. C. A Role for Electrospray Mass-Spectrometry in Electrochemical Studies. Anal. Chem. 1995, 67, 1691-1695.

22. Xu, X.; Lu, W.; Cole, R. B. On-Line Probe for Fast Electrochemistry/Electrospray Mass Spectrometry. Investigation of Polycyclic Aromatic Hydrocarbons. Anal. Chem. 1996, 68, 42444253.

23. Arakawa, R.; Abura, T.; Fukuo, T.; Horiguchi, H.; Matsubayashi, G. Analysis of Electrolysis Reactions of Metal Complexes Using On-Line Electrospray Ionization Mass Spectrometry with a Compact Electrolytic Flow-Through Cell. Bull. Chem. Soc. Jpn. 1999, 72, 1519-1523.

24. Pretty, J. R.; Van Berkel, G. J. Electrochemical Sample Pretreatment Coupled On-Line with Electrospray Mass Spectrometry for Enhanced Elemental Analysis. Rapid Commun. Mass Spectrom. 1998, 12, 1644-1652.
25. Deng, H.; Van Berkel, G. J. Electrochemical Polymerization of Aniline Investigated Using On-Line Electrochemistry/Electrospray Mass Spectrometry. Anal. Chem. 1999, 71, 4284-4293.

26. Kertesz, V.; Van Berkel, G. J. Electropolymerization of Methylene Blue Investigated Using On-Line Electrochemistry/ Electrospray Mass Spectrometry. Electroanalysis 2001, 13, 1425-1430.

27. Deng, H.; Van Berkel, G. J. A Thin-Layer Electrochemical Flow Cell Coupled On-Line with Electrospray-Mass Spectrometry for the Study of Biological Redox Reactions. Electroanalysis 1999, 11, 857-865.

28. (a) Jurva, U.; Wikström, H. V.; Bruins, A. P. In Vitro Mimicry of Metabolic Oxidation Reactions by Electrochemistry/Mass Spectrometry. Rapid Commun. Mass Spectrom. 2000, 14, 529 533. (b) Permentier, H. P.; Jurva, U.; Barroso, B.; Bruins, A. P. Electrochemical Oxidation and Cleavage of Peptides Analyzed with On-Line Mass Spectrometric Detection. Rapid Commun. Mass Spectrom. 2003, 17, 1585-1592.

29. Modestov, A. D.; Srebnik, S.; Lev, O.; Gun, J. Scanning Capillary Microscopy/Mass Spectrometry for Mapping Spatial Electrochemical Activity of Electrodes. Anal. Chem. 2001, 73, 4229-4240.

30. Diehl, G.; Karst, U. On-line Electrochemistry-MS and Related Techniques. Anal. Bioanal. Chem. 2002, 373, 390-398. 